\title{
Impact of Social Media Addiction on Adolescent Health
}

\author{
Sevilla Ukhtil Huvaid ${ }^{1}$, Yulianita ${ }^{2}$, \\ \{sevilla.kesmas@gmail.com, yuliazallia@gmail.com\} \\ Faculty of Public Health, Baiturrahmah University, Padang, Indonesia ${ }^{1,2}$
}

\begin{abstract}
Addiction to the use of social media can make teens suffer from health problems. The purpose of this service is to increase students' knowledge and understanding of the negative impact of excessive use of social media on aspects of their health. This activity was carried out at SMAN 9 Padang. The methods included a pre-test, presentation, video screening, discussion, sharing experiences, and post-test. The results of the pre-test and post-test showed there was a change in the form of increased knowledge of participants. Based on experiences from the students, it can be seen that there is still a lack of support given by the Public Health Service, schools, and families. It is suggested that health professionals have an intensive effort to promote and evaluate the existing cases of social media addiction. The school also needs to issue a policy or hold a meeting with the family.
\end{abstract}

Keywords: Social Media, Addiction, Adolescent, Health

\section{Introduction}

Social media is an internet-based application group that can easily invite anyone interested to participate by responding openly or sharing information, and establishing communication in a very short time, does not require a lot of money, and without distance restrictions. The presence of social media certainly has a huge influence on people's lives, and teenagers are no exception.

The adolescent phase is a transition period where someone has left childhood, but also has not yet entered adulthood. In this phase, someone will always be interested in new things. Teenagers who have social media usually post about their personal activities, their opinions, and their photos, to describe their lifestyle.

According to Garrison in Ali (2014), adolescents have seven distinctive needs, namely the need for affection, the need for participation and acceptance in groups, the need to be independent, the need for achievement, the need for self-recognition of others, the need to be valued, and the need to obtain the philosophy of life intact. Based on these needs, it is not surprising that so many teenagers who are active in various social media have even become addicted to make them obliged to visit the site every day [1].

American Common Sense Media advocacy group of more than 1,000 teenagers aged 1317 years prove that two-thirds of respondents claimed that they send messages every day, in which half said they visited social media sites every day. A quarter of adolescents use at least two types of social media in a day [2].

In Indonesia alone, based on the results of research conducted by the Ministry of Communication and Information, UNICEF, and Harvard University of 400 teenagers aged 10- 
19 years who were sampled as representing 11 provinces, it is known that nearly $80 \%$ of adolescents are addicted to social media. Most teenagers use social media for things that are not appropriate, $24 \%$ claim to use social media to interact with strangers, $14 \%$ access pornographic content, and the rest for online games and other interests [3].

Addicted to social media can attack anyone, especially among adolescents who are at the stage of an identity crisis, they tend to have a high curiosity and are easily influenced by their peers [4]. However, a social media addict often feels that he is not addicted and does not even want to be called an addict because he does not realize that his online behavior is excessive.

Teenagers, as one of the users of social media, have not been able to sort out information and communication, which can bring benefits to them. They also tend to be easily influenced by the social environment without first considering what positive or negative impacts they will receive [5]. As we know, social media is a place for teenagers to express their freedom of expression, whether it is in the form of images or sometimes misleading messages. Information that is spread through social media is routinely seen, leading to the formation of opinions among adolescents.

Teenagers who are addicted to social media usually prefer this online media to interact socially because they feel they have freedom of expression. In contrast, when interacting directly, they sometimes have difficulty in disclosing themselves so that there are concerns whether other people will accept or reject him. Besides that, through social media, they can also interact freely without any strict supervision or control from parents and teachers.

According to H. M. Orzack, social media addiction is a disorder that arises in people who feel that the virtual world is more interesting than the real world. It is marked by the inability of a person to control their internet time. Meanwhile, according to Kimberly S. Young, addiction to social media is a syndrome that is characterized by an endless amount of time. Itis very much in using social media and unable to control their use while online, so it becomes a problem when it interferes with other parts of their lives such as sleep, work social relations, and so on. Usually, the time used by social media addicts in surfing is between 20 to 80 hours per week. Whereas individuals who are normal in using social media only use the internet between 4 to 5 hours per week [6].

Based on the results of a study conducted by the Associated Chamber of Commerce and Industry of India (ASSOCHAM) in 2000 adolescents in India with an age range of 12-20 years proved that the majority of respondents stated addicted to the use of social media has made them experience health problems such as insomnia, depression, and reduced personal relationships with their real-world counterparts [7].

SMA 9 Padang City is one of the state high schools in West Sumatra Province. This school has grown rapidly to become one of the favorite schools in the city of Padang. In fact, in 2015, it was recorded as the second high school that was most sought after by applicants from prospective students. One of the driving factors is its strategic location close to the Cyber Pasar Baru area and the Andalas University campus. The location of SMA 9, which is near Andalas University campus, may also influence students' health and learning achievements. There are many internet cafes which can be used by anyone, including students, to access social media. By cheaper cost online, the students have a high possibility of being a social media addict. Moreover, SMA 9 Padang also has no counseling program for students about the negative impact of social media on their health and learning achievement. 


\section{Method}

This dedication activity was carried out at SMAN 9 Padang, in collaboration with the Principal and local teaching staff. The methods included:

The work steps carried out are:

1. Participants in the extension work on the pre-test

2. Participants get exposure to material about the impact of social media addiction on health and learning achievement

3. Video display about social addiction disorder

4. Extension participants and speakers conduct discussions (questions and answers) about the material that has been presented

5. Extension participants work on post-tests

6. The extension participants shared their experiences/ stories about the impact of the excessive use of social media they felt

7. Counseling participants compete to answer questions about the material provided by the community service team to get a door prize

In the implementation of this counseling, the role of the Principal and teachers in SMA 9 Padang City is very much needed. To carry out this activity, the school is willing to provide a place and time for the activity. In addition, the partners will also provide facilities related to activities that support the smooth and smooth running of activities.

In order for the activity to go as expected, the community service team will also evaluate by holding a discussion and question and answer session with the participants. This discussion session aims to make the knowledge and understanding provided as expected so that there are no mistakes in understanding the knowledge obtained by the counselors.

\section{Result}

The activity began with an agreement of cooperation between the Faculty of Public Health of the University of Baiturrahmah and the 9th High School of Padang City to carry out Community Service activities through counseling activities that were planned to be given to 40 students who were representatives in each class. Of all the targeted students, it turned out that only 20 students were present and attended counseling from the beginning to the end of the activity. It is because there has not been even coordination between the school leaders and teachers related to the service program. In consequence, several teachers give daily exams at the same time.

The outreach involving the 20 students showed an encouraging thing because the participants responded positively and were very enthusiastic about participating in the extension activities, both during the material exposure session and during the discussion session. While the test results of the counseling participants, both pre-test and post-test, can be seen in the following table:

Table 1. Evaluation Results of Participants' Counseling Knowledge

\begin{tabular}{clc}
\hline No & \multicolumn{1}{c}{ Variable } & Mean \\
\hline 1 & Knowledge Before Counseling & 7,38 \\
2 & Knowledge After Counseling & 8,05 \\
\hline
\end{tabular}


The pre-test and post-test values indicate there has been a change in respondents' knowledge before counseling (7.38) and after counseling (8.05).

The supporting factors in the implementation of this activity include the considerable interest and enthusiasm of the participants, the schools that want to give permission, and provide facilities, as well as a solid community service team so that counseling can run well. While the inhibiting factors include the conflicting schedule of service activities with the daily exam schedule. In addition, the sound system problem also has limited time to deliver the counseling material in the first session.

\section{Discussion}

The results mentioned above indicate that counseling about the impact of social addiction disorder on adolescent health carried out can increase students' knowledge and motivation in preventing excessive use of social media. However, there are still 20 students out of 20 who have not shown an increase in knowledge after counseling, the possibility of general knowledge support and their educational background is inadequate or perhaps also due to the influence of unfocused participation in activities.

Knowledge of something is very important for every individual in determining actions. Good knowledge of a matter tends to improve the quality of its actions. Increasing or lack of knowledge affects one's understanding, ways of thinking, and analyzing something so that it will automatically give different perceptions to the observed object, which will ultimately change one's behavior.

The purpose of counseling is to increase students' knowledge and motivation to avoid the effects of social media addiction. It can be described as follows: first, to increase their knowledge of the negative impact of social media, both on health and learning achievement. Second, to develop their attitudes and motivations to be smart in using social media. Third, to form their behavior in a preventive effort from social media addiction.

The extension participants had an opportunity to discuss with the speaker and the team about the topic. They also share their experiences on the impact of using social media. This counseling showed a positive response from the participants. They are very interested during the discussion, and some could not ask their question because of limited time. Some questions indicate that the students have a limited understanding of the issue. However, their undestanding is increased after the discussion. During the discussion, it can also be seen that there is still a lack of attention and support given by the Puskesmas, schools, and families to increase their knowledge about the impact of unnecessary use of social media.

Besides counseling, the team also provides door prizes for the participants. Every participant who successfully answers the questions raised by the community service team related to the training material, then they have the right to choose and get a gift that has been prepared by the community service team. This activity was successful because participants are engaged during the counseling activity. 


\section{Conclusion}

The activity has a positive impact on increasing participant knowledge. They were also very interested in discussing and sharing their experiences during the session. During the counseling, the participants indicated that there was still the limited effort of the Public Health Service, schools, and families to increase students understanding of the impact of excessive use of social media.

It is suggested that health professionals have an intensive program to promote and evaluate social media addiction by initiating a meeting with the school. Moreover, the school also needs to issue a policy or hold a meeting with the family to discuss the impact of excessive use of social media on health and student achievement.

\section{References}

[1] Ali, Mohammad, dkk.: Psikologi Remaja (Jakarta : PT. Bumi Aksara). (2014)

[2] Hajani, Febyuka.: Peningkatan Kebutuhan akan Media Sosial pada Remaja (Diakses dari : http://www.personalgrowth.co.id/en/journal- viewarticle.php/id=91). (31 Juli 2018)

[3] Hapsari, A \& Ariana, A. D.: Hubungan antara Kesepian dn Kecenderungan Kecanduan Internet pada Remaja (Jurnal Klinis dan Kesehatan Mental). 164 - 171 (2015)

[4] Sarwono, S. W.: Psikologi Remaja (Jakarta : PT. Raja Grafindo Persada). (2013)

[5] Ekasari, P \& Dharmawan, A.: Dampak Sosial Ekonomi Masuknya Pengaruh Internet dalam Kehidupan Remaja di Pedesaan (Bogor : Fakultas Ekologi Manusia IPB). (2012)

[6] Basri, A. Said Hasan.: Kecenderungan Internet Addiction Disorder Mahasiswa Fakultas Dakwah dan Komunikasi ditinjau dari Religiositas (Jurnal Dakwah, Vol. XV, No. 2). (2014)

[7] Firman, $M$ \& Ngasis, A.: Pengguna Internet Mulai Bosan Media Sosial (Diakses dari : http://teknologi.news.viv.co.id/news/read/282747-pengguna-internet-mulai-bosan-media-sosial). (1 Agustus 2018). 